\title{
INSTITUTIONAL ANALYSIS OF THE CONTEMPORARY REGIONAL LABOUR MARKET IN THE CZECH REPUBLIC
}

\author{
Václav Novák, Marek Vokoun, František Stellner, Marek Vochozka
}

\section{Introduction}

In this study we analyse labour economic policy instruments, which are present in current regional labour markets. The framework of our analysis is based on the perceptions of important institutional players who are in direct daily contact with both sides of the market. Both labour offices and private recruitment agencies are critical institutional players in the labour market. Their ability to assess economic policies and market outcomes (employment and unemployment) provides a unique basis for institutional analysis.

Our hypotheses deal with public institutions and their ability to provide good quality labour market economic policies. A questionnaire was used to collect data from selected institutions and then to test our hypotheses. The expectations are that there would be differences in the way public policy is perceived by the public and private sectors and in the perception of the labour market as an economic phenomenon in the selected regions.

This study starts by introducing the socioeconomic differences between the regions followed by an examination of the economic policies that are dominant in the regional markets. The economic theories and current empirical results dealing with public policy effectiveness in the area of employment policy are then subjected to a critical review. The institutional analysis is predominantly focused on empirical evidence and the hope is that it is possible to also deliver a public policy recommendation, which will make the employment policies and their instruments more effective given the current institutional infrastructure.

Economists traditionally view institutions and scarce resources as a framework for economic activity (Aoki, 2001). Institutions are usually perceived to be players in a game i.e. decision makers, entrepreneurs, and politicians who can substantively influence the whole economy. But in the game theoretic approach and in our analysis the institutions are the rules of the game which constrain and shape human interactions (North, 1991), not the players.

These formal and informal institutions in the labour market are the target of this research study. Formal institutions are for example the employment policies, the minimum wage, policies regarding secondary and tertiary education, EU labour market policies, etc. The informal institutions are usually not visible to an impartial spectator or an economic analyst. These informal institutions include social norms, traditions and customs, which can significantly change and influence labour market outcomes and the economic activity of labour market players (Ostrom, 1990). To shed some light on the efficiency of the formal and informal rules we carried out an analysis of the experience of major institutional players in the labour market.

\section{Labour Market Players and Rules of the Game}

The Czech labour market is influenced by many economic agents (players). There are private and public sector players, both on the demand and supply side. The main players are public administration officers (European, national, regional), employers, unions, educational institutions and non-governmental (not-forprofit) organisations. Those players shape the rules of the game; however it is the state economic policy, which defines the actual rules of the game in the labour market.

The individuals (supply side) are the targets of programmes and policies financed by public funds (national and European). These programmes are focused on preparation (education) and adaptability (requalification, mobility, and lifelong learning), and ensure 
socially acceptable conditions (benefits) for unemployed citizens who are in danger of being permanently excluded from the labour market.

There is also public support aimed at the demand side (employers). There are public employment agencies, which provide information about vacant jobs and programmes for employers. There are employment programmes aimed at people with disabilities, employers in insolvency, and other incentive programmes for employers.

In other words, the public sector uses socalled "passive" employment policies that cover all the supply-side subsidies and benefits. There are also so-called "active" employment policies, which consist of all kinds of policy instruments. The main instruments are retraining and requalification programmes, community work, socially beneficial jobs, sheltered workshops, and consulting services at labour offices. There are also other instruments, which provide all kinds of incentives (to start a new company) and support (to increase mobility) to applicants.

The labour market outcomes are influenced by all kinds of interwoven rules of the game. This includes structural economic policy, higher education policy, anti-cyclical economic policy, labour tax policy, trade regulations, labour safety and other labour regulations. These economic policies interact and simultaneously influence the demand and supply sides and the behaviour of all the labour market players. Comprehensive overviews of institutions that influence the Czech labour market are summarised in Tvrdoň (2008).

According to the Czech Ministry of Labour and Social Affairs, youth unemployment and the overall situation in the labour market is better than in the rest of the EU (MPSV, 2015). In comparison to other so called transitional economies, the Czech Republic has achieved similar employment numbers with regards to the economically active population to the situation in Germany, which by EU standards is considered to have a well-performing labour market (Bah \& Brada, 2014). These EU standards are the target of critique from leading EU political parties. The European and Czech labour markets are considered to lack flexibility and the current "active and passive" instruments of employment policies are viewed as being inefficient.

\section{Employment and Labour Market in the Czech Republic}

According to economic theory the ability to get a job heavily depends on the quality of the individual level of human capital investment and subjective job preferences. Traditionally the wage, which is an outcome of a particular labour market, is influenced by qualifications, age, experience, health status, family background and shared values (Mincer, 1958). These are individual traits that in the Czech environment are heavily influenced by the dominance of public education. However, no recent studies have explicitly dealt with this issue in the Czech context.

Dill and Soo (2005) suggest that the quality of education should be compared through a system of league tables and a university ranking system in order to stimulate improvements. Privatisation in education also contributes to diversification, new partnerships, and provides incentives based on competition, which is not present in most publicly financed environments (Ball, 2009). However, the debate about the public-private divide in education is rather complicated because it is in general considered to be a non-rivalry, non-excludable, public good. In higher education, the situation is not as clear and some economists question the public good of university education, which is full of rivalry, exclusive and broadly speaking a private to "mixed" good. However, the nature of education as a public good is not the central issue of this paper and requires additional research.

Economic analysts are interested in particular rules of the game - economic policies. High taxation, generous welfare state, and other labour market rigidities can reduce motivation. The consequence is that some people choose to live on benefits (Flek \& Večerník, 2005). It can and does increase the role of informal institutions (grey economy) and leads to tax evasion (Slemrod, 2007). It is suggested that these effects are present regardless of the economic level of the country (Gërxhani \& Schram, 2006). The mobility of labour is influenced by a rigid and regulated housing market, which was the case in the Czech Republic. The current deregulation process in the housing market has been partially successful in bringing about change but the unwillingness to move for work due to social and cultural factors prevails (Vlček, 2010). 
In general, policies aimed at labour market flexibility can significantly improve labour market outcomes and economic growth (Kahn, 2012).

A minimum wage is a traditional tool which according to liberal classic economic theory cannot work. This policy produces so-called "unwillingly" unemployed individuals, which are unable to find a job for a wage, which is lower than the minimum wage. These individuals are subsequently forced to live on benefits and are not motivated to search for a job, or alternatively they participate in the grey economy (Wawrosz, Heissler, \& Mach, 2012). The actual impact of the minimum wage in the Czech Republic is inconclusive (Pavelka, Skála, \& Čadil, 2014). Another analysis shows that there were years when it was better not to have a minimum wage job because living on benefits provided more money and free time (Pavelka, 2012).

In the 1990s, employment policy that included all kinds of unemployment and social benefits did not resolve the issue of unemployment in the Czech labour market (Sirovátka \& Mareš, 2006). On the whole, an active employment policy is considered more efficient than a passive one (Gupta \& du Toit, 2009; Rašovec, 2014). This literature review is mostly based on papers dealing with real economic data. Qualitative institutional research is missing. This study provides an insight into the actual experience of the major players under current policies (rules) in the regional labour markets. An analysis follows of the regions and their differences.

\section{Socio-Economic Differences in the Analysed Regions}

The Ústecký Region (UR) is located in the north-west part of the Czech Republic (CR). It is the fifth largest region in terms of the number of inhabitants (more than 820,000 ). In size, it is a small region with an above average population density. The Jihočeský Region (JR) is located in the south part of the Czech Republic. It is the seventh largest region in terms of the number of inhabitants (more than 630,000 ). In terms of size, it is the second largest region with a below average population density. During the last 20 years, the numbers of inhabitants in both regions have been growing (see Tab. 1). The GDP per capita in both regions is below average for the Czech Republic. The age structure has shifted dramatically. On average the population is ageing. In 2013 , in both regions, the population over 65 years of age was larger than the population of $1-15$ years of age. The population growth rate and gross migration rate is positive in both regions, however, more people are moving out of the Ústecký Region in comparison to the Jihočeský Region.

\section{Tab. 1: Regional socioeconomic indicators - the Jihočeský Region, the Ústecký Region and the Czech Republic (1994-2013)}

\begin{tabular}{l|r|r|r|r|r|r}
\multirow{2}{*}{\multicolumn{1}{c|}{ Indicator }} & \multicolumn{3}{|c|}{$\mathbf{1 9 9 4 - 2 0 0 3}$} & \multicolumn{3}{c}{$\mathbf{2 0 0 4 - 2 0 1 3}$} \\
\cline { 2 - 7 } & \multicolumn{1}{c}{ JR } & \multicolumn{1}{c|}{ UR } & \multicolumn{1}{c|}{ CR } & \multicolumn{1}{c}{ JR } & \multicolumn{1}{c}{ UR } & \multicolumn{1}{c}{ CR } \\
\hline Average population $\left(10^{3}\right)$ & 626.1 & 824.3 & $10,271.8$ & 633.1 & 828.0 & $10,398.6$ \\
\hline Population density (inhabitants $\left./ \mathrm{km}^{2}\right)$ & 62.3 & 154.6 & 130.2 & 63.0 & 155.2 & 131.9 \\
\hline Age index $(1994,2013)$ & 65.7 & 59.9 & 69.6 & 116.0 & 105.1 & 115.7 \\
\hline Crude birth rate (\%) & 9.2 & 9.8 & 9.1 & 10.4 & 10.8 & 10.6 \\
\hline Crude mortality rate (\%) & 10.5 & 11.0 & 10.9 & 10.1 & 10.8 & 10.3 \\
\hline Infant mortality (\%) & 5.8 & 7.9 & 5.4 & 2.7 & 4.9 & 3.0 \\
\hline Net migration (\%) & 1.2 & 1.5 & 0.9 & 1.4 & 1.3 & 3.0 \\
\hline Average GDP per capita $\left(10^{3} \mathrm{CZK}\right)^{*}$ & 211.3 & 192.5 & 226.2 & 311.1 & 289.4 & 362.3 \\
\hline Average unemployment rate (\%) & 4.5 & 11.4 & 6.4 & 4.8 & 11.2 & 6.8 \\
\hline
\end{tabular}

Source: Czech Statistical Office: Demographic Yearbook of Regions 2004-2013, Czech labour market - Time Series 1993-2013, Public Database - The population in the selected area - time series 1991-2014; own calculations

\footnotetext{
* Average GDP in the first period covers years 1996-2003, CZK - local currency
} 
The industrial structure of both regions differs substantially. The Jihočeský Region has favourable natural conditions, which means more people in the region are employed in agriculture, fishing and forestry $(7.6 \%$ in $\mathrm{JR}$, $4.5 \%$ in $\mathrm{CR}$, and $3.5 \%$ in UR). The natural conditions in the Ústecký Region dictate that more people are employed in mining $(4.0 \%$ in UR, $1.4 \%$ in CR). The share of employees in the electricity, gas and heat manufacturing and distribution sectors is above the national average because of the thermal power plants in UR and the nuclear power plant Temelín in JR. In UR, employment in services such as transportation and warehousing is above average. In JR, the situation in services is different. People are employed in tourism because the region has many cultural points of interest and UNESCO listed sites.

\begin{tabular}{|c|c|c|c|c|c|c|c|c|c|}
\hline $\begin{array}{l}\text { The educational stru } \\
\text { and the Czech Repu }\end{array}$ & $\begin{array}{l}\text { e (\%) } \\
(1991\end{array}$ & $\begin{array}{l}\text { the } \\
2001\end{array}$ & hoč & ký F & gion & le Ú & ecký & & \\
\hline \multirow{2}{*}{ Educational level } & \multicolumn{3}{|c|}{ Jihočeský Region } & \multicolumn{3}{|c|}{ Ústecký Region } & \multicolumn{3}{|c|}{ Czech Republic } \\
\hline & 1991 & 2001 & 2011 & 1991 & 2001 & 2011 & 1991 & 2001 & 2011 \\
\hline Basic, pre-primary & 34.3 & 23.8 & 18.8 & 38.9 & 27.9 & 23.2 & 33.5 & 23.3 & 18.5 \\
\hline Secondary education without GCE & 35.6 & 39.2 & 36.2 & 36.0 & 40.1 & 37.2 & 35.7 & 38.5 & 34.9 \\
\hline Secondary education with GCE & 23.4 & 28.8 & 32.9 & 20.3 & 25.7 & 30.3 & 23.2 & 28.7 & 32.9 \\
\hline Tertiary education & 6.4 & 7.9 & 11.6 & 4.4 & 5.5 & 8.4 & 7.2 & 9.0 & 13.2 \\
\hline Without education & 0.4 & 0.4 & 0.5 & 0.5 & 0.8 & 1.0 & 0.3 & 0.4 & 0.6 \\
\hline
\end{tabular}

Source: Czech Statistical Office: Předběžné výsledky sčitání lidu, domů a bytů - Česká republika a kraje - 2011; own calculations

The educational structure fundamentally changed in both regions and throughout the Czech Republic after 1989 (Tab. 2). The share of tertiary educated and secondary educated with GCE increased. The proportion of people with basic education significantly reduced. The educational structure has similar values in the Jihočeský Region as throughout the state, although this region still has a lower percentage of people with tertiary education. Educational structure of the population is long-term very unfavourable in the Usti region. Compared with the national average, there is a higher proportion of people aged 15 or over with no education or only basic education and of tertiary educated and secondary educated with GCE.

Between 1993 and 2014 the overall level of employment declined in the Jihočeský Region

\begin{tabular}{|c|c|c|c|c|c|c|c|}
\hline Tab. 3: & $\begin{array}{l}\text { Employment structure } \\
\text { the Ústecký Region an }\end{array}$ & $\begin{array}{l}\text { in indu } \\
\text { e Czecr }\end{array}$ & $\begin{array}{l}\text { secto } \\
\text { epublic }\end{array}$ & $\begin{array}{l}- \text { the } \\
1993,2\end{array}$ & $\begin{array}{l}\text { očesky } \\
\text { 4) }\end{array}$ & Region, & \\
\hline & Inductrov coctor & Jihočesk & Region & Ústecky & Region & Czech R & public \\
\hline & Inaustry sector & 1993 & 2014 & 1993 & 2014 & 1993 & 2014 \\
\hline Mining ar & $\mathrm{d}$ quarrying & 0.4 & 0.2 & 7.2 & 1.7 & 2.6 & 0.7 \\
\hline Manufact & uring & 25.5 & 27.6 & 26.5 & 25.5 & 28.8 & 26.7 \\
\hline $\begin{array}{l}\text { Electricity } \\
\text { supply }\end{array}$ & gas, steam and air condit. & 1.9 & 2.0 & 2.9 & 1.8 & 1.6 & 1.1 \\
\hline $\begin{array}{l}\text { Water su } \\
\text { and rem. }\end{array}$ & $\begin{array}{l}\text { ply, sew., waste man., } \\
\text { act. }\end{array}$ & 0.8 & 0.9 & 1.0 & 1.2 & 0.8 & 1.1 \\
\hline Industry & & 28.6 & 30.7 & 37.5 & 30.2 & 33.8 & 29.7 \\
\hline
\end{tabular}

Source: Czech Statistical Office: Labour Market in the Czech Republic - Time Series - 1993-2014; 
and the Ústecký Region, while in the whole country increased (Tab. 3). There was the drop of $2.5 \%$, in the Jihočeský Region; the Ústecký Region recorded a significant decline $-8.3 \%$. This stems from the structure of the industry, which was markedly different in both regions in the early $90 \mathrm{~s}$. In the Ústecký Region, mining and quarrying played an important role in the early 90 s an. In 1993, it gave this sub-sector job for more than $7 \%$ of employed people there. In 2014, the share of this sector on employment was less than 2 percent in the Usti region. In the reporting period, employment in the industry decreased by a significant 7.3 percentage points in the Ústecký Region. The Jihočeský Region showed an increase in industrial employment of 2.1 percentage points for the same period.
The reason was an increase in employment in manufacturing. It's almost unbelievable, but Jihočeský Region presented a higher share of employment in the industry sector than the Ústecký Region in 2014.

There are differences in the development of the employment rates in both regions (Fig. 1). In UR the employment rate fell to $87 \%(1993=100 \%)$ in 2000 . In the years that followed it fluctuated around $90 \%$. The developments in the Jihočeský Region were very similar to that of the national average. The economic crisis affected the Jihočeský Region more severely than the Ústecký Region. The decline in employment was lower, with even a slight increase in employment being observable in 2013.

\section{Fig. 1: Employment development in the Jihočeský Region and the Ústecký Region (1993-2013)}

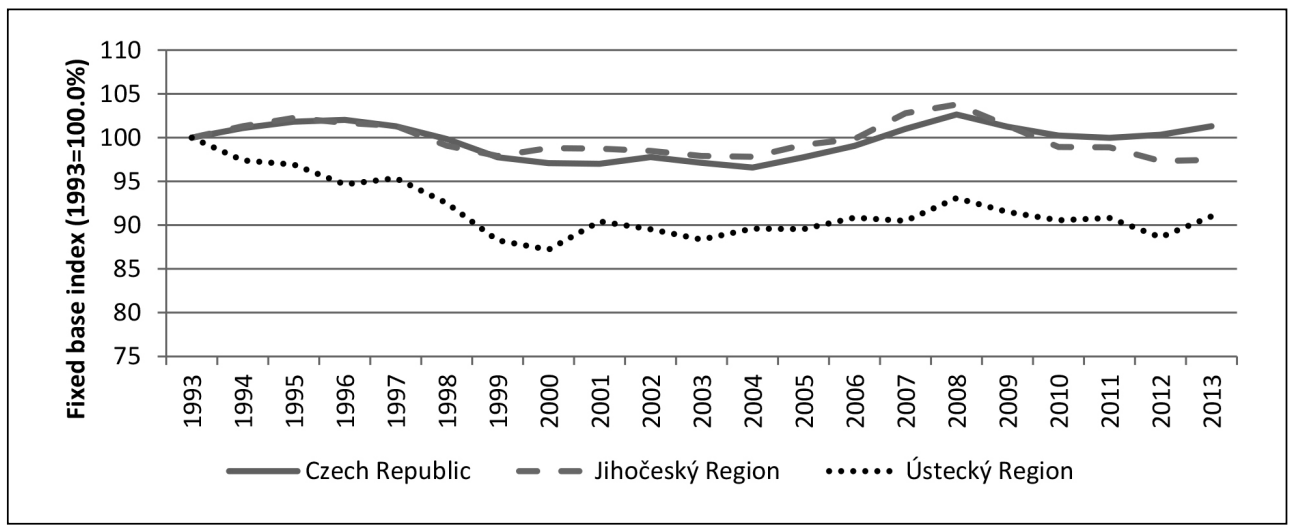

Source: Czech Statistical Office: Czech labour market - Time Series - 1993-2013

Substantive differences exist between the regions with regards to both the employment rate and unemployment rate (see Fig. 2). JR and almost all its districts belong to the group of regions with the lowest unemployment rates. In contrast, UR and its districts suffer from the highest unemployment rates and naturally is the target of national public support and EU development programmes. The unemployment rate in the CR and both regions was similar in 1993. The transformation process was based on structural changes to large industrial companies which as a consequence resulted in an increase in the rate of structural unemployment. The unemployment rate peaked in 2000 and the difference in the rate between the two regions reached about $10 \%$ (Fig. 2).

The unemployment rate fluctuated between 2000 and 2004. Until the start of the economic crisis in 2008 , the rate was decreasing and the differences between the two regions became smaller (about 5\%) in comparison to the situation in 2000. This period after the so-called currency crisis which also hit the Czech economy was studied by Holátova and Řehoř (2006) and Toušek et al. (2005). They concluded that there were significant socioeconomic differences between regions and that the key factors causing regional differences were the quality and activity of human capital. 


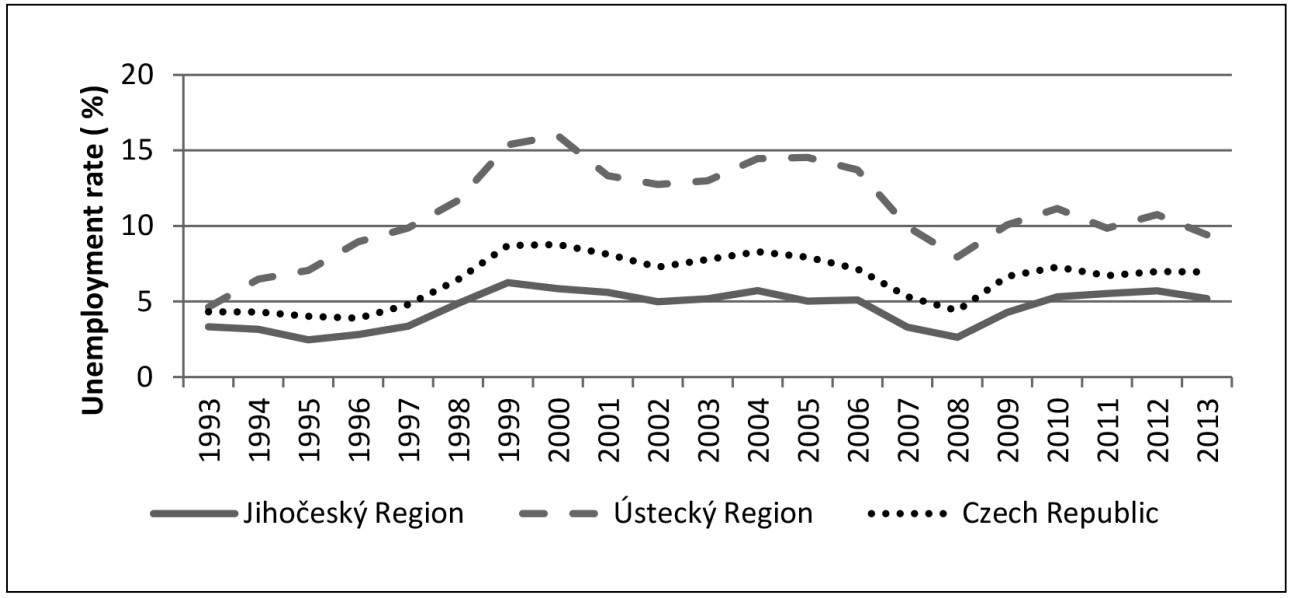

Source: Czech Statistical Office: Czech labour market - Time Series - 1993-2013

After the beginning of the economic crisis, the unemployment rate started to rise in both regions. The developments between 2009 and 2014 suggest that the impact of the economic crisis was more severe in the JR. One of the explanations for this is that large scale public support and economic policies were targeted at UR which helped to significantly ease the negative effects of the economic crisis. The difference between the regions in terms of their unemployment rates was the lowest in 2013, but this does not compare well with the lowest difference in the rates which was achieved in 1993 (1.3\%).

\section{Data and Methods}

The institutional analysis was aimed at labour offices and their departments. The control group in our analysis was represented by a selection of private employment agencies and human resources (HR) departments of some of the largest employers in the region. We asked the respondents to fill in an electronic questionnaire (Appendix 1), which consisted of several employment policy questions. For the evaluation of a policy instrument, the Likert scale was used whereby 1 represented a highly beneficial instrument and 5 an inappropriate instrument.

The questionnaire was successfully sent to 290 officials in leading positions who represent the institutional sphere of public employment policy in March 2015. The return rate was moderate $(22 \%, 64$ respondents). We believe that this was due to the fact that many employees were on leave and that some of the email addresses did not work. The control group consisted of 28 respondents $(11.2 \%$ return rate, 250 private recruitment agencies or HR departments of large firms).

To test the hypotheses, we utilised parametric and non-parametric tests because the data was not always normally distributed. The standard unpaired t-test (Welch, 1947) would in "not normal" cases possibly provide biased results. The two-sample hypotheses were therefore tested using the Wilcoxon rank-sum test (Wilcoxon, 1945) which is an unmatched data equality test for two independent variables X1 (for example one regional group) and $\mathrm{X} 2$ (a selected public policy question number $\mathrm{Q}$ ).

This rank-sum test is reflected in the Wilcoxon statistics of the single z-test, which tests the null hypothesis of equality on a sample of $n$ observations. For this purpose, the probability of a Type I error was determined as $\alpha=5 \%(p<0.05)$. The significant mean difference between the groups is used as a rough approximation of equality dissimilarities under the ceteris paribus condition with no allowance given for multiple variable interactions. 


\section{Hypotheses}

This study is generally interested in the differences in evaluation of employment policies by the major players in the regional markets. The first hypothesis deals with significant differences in the perception of labour market policies (rules of the game) between the public and private sectors. The second hypothesis deals with regional differences in the perception of labour market policies between the Ústecký Region and the Jihočeský Region. The results will be compared in respect to the actual socioeconomic differences.

The selection of the regions is predominately based on high regional differences in unemployment rates, GDP per capita and educational structure. In other words there is a higher share of low educated inhabitants, lower GDP per capita and higher unemployment in the Ústecký Region). Current regional analysis stresses the role of the socioeconomic differences based on the "The North/ South" divide, which is typical for countries like England, Italy and Spain (González, 2011). Although the situation is more complicated in the Czech Republic and more research is needed, but this paper also contributes to this debate. Southern regions (NUTS 2 regions Jihovýchod and Jihozápad) have in fact (CZSO 2015) on average higher GDP per capita than their counterpart northern regions (NUTS 2 regions Severovýchod and Severozápad).

Our hypotheses testing are heavily dependent on the context of the economic crisis of 2008. Average unemployed person's annual costs were 51,886 CZK between 2005 and 2014 (Appendix 2). The average costs (active, passive and other employment market policies expenditures per unemployed person) increased substantially in 2008 (68,229 CZK) and 2009 (65,684 CZK). Although the total average costs fluctuated around the average value between 2010 and 2013, the active employment market policy expenditures were lower than the average value $(15,126 \mathrm{CZK})$ in 2009 and between 2011 and 2013 (see Appendix 2).

In the case of Ústecký and Jihočeský Regions, all kind of employment policies were introduced between 2005 and 2015. There are some differences (mobility programmes in Jihočeský Region) in their policy aims but the general focus is the same (long-term unemployment reduction, integration etc.) In the questionnaire, the respondents were asked about rather traditional active employment market policies (AEMPs). There were, however, more programmes based on EU funds, which were introduced to complement and make AEMPs more effective between 2007 and 2013. The Human Resources and Employment Operational Programme was targeted at traditional AEMPs but also on individual multiobjective projects (for example sheltered housing with a subsequent business project). Those programmes are not considered directly in our questionnaire but were mentioned by our respondents as very innovative and possibly more long-term effective than traditional EMPs. The other programmes like support for absolvents and investment incentives were discontinued but they were also used by the regional labour offices.

\section{Results}

The statistics for employment policy (see Tab. 2) show only two normally distributed results in the public sphere. On average, passive policy is perceived to be the worst policy instrument by responsible head officers and employment policy workers. In contrast, the instrument oriented towards the employment of persons with disabilities scored very highly. The rest of the analysed instruments have skewed distributions and a high variability of responses. We must assume that there are therefore differences between the groups of respondents.

The statistics also show that there are no significant differences between the public officers in both regions. This result suggests that the perceptions of current active employment policy instruments are independent of regional employment and unemployment rates. The average effectiveness of active employment policy instruments is below the average for the Likert scale (2.5), which suggests a high level of scepticism towards the appropriateness and efficiency of the instruments. On average, the best, and not as badly perceived instrument, is the public support for socially useful jobs.

Retraining is perceived by our selected sample of private recruitment agencies and HR departments of large firms to be (by $+0.83 \%$ points) a better instrument $(z=3.42$; $n=92)$ than the officers' average $(2.06 \%)$. The only conformity among the public and private sphere is in the area of passive employment policy. All the other instruments were perceived 
by the private sector to be better (see Tab. 4). This suggests that the private sector perception is biased. They do not see all the unsuccessfully retrained unemployed like their counterparts in labour offices do.

\section{Tab. 4: Employment policy evaluation - private sector differences}

\begin{tabular}{l|c|c|c|c|c}
\multicolumn{1}{c|}{$\begin{array}{c}\text { Labour economic policy } \\
\text { instrument }\end{array}$} & \multicolumn{2}{c|}{$\begin{array}{c}\text { Std. deviation } \\
\text { Normality }\left(^{*}\right) \\
\text { Mean (in \%) } \\
\text { (Officers }=64)\end{array}$} & $\begin{array}{c}\text { Score difference } \\
\text { Private sector } \\
\text { (in \% points) } \\
\text { (Agents = 28) }\end{array}$ & $\begin{array}{c}\text { Statistics } \\
\text { (N = 92) }\end{array}$ \\
\hline Retraining & 0.794 & & $2.06 \%$ & $+0.83 \%$ & $\mathrm{z}=3.42$ \\
\hline Community work & 1.035 & & $1.77 \%$ & $+1.02 \%$ & $\mathrm{z}=4.08$ \\
\hline Socially useful job & 0.833 & & $1.56 \%$ & $+1.15 \%$ & $\mathrm{z}=4.92$ \\
\hline Counselling & 0.873 & & $2.00 \%$ & $+1.25 \%$ & $\mathrm{z}=4.76$ \\
\hline Persons with disabilities & 0.865 & $*$ & $1.83 \%$ & $+0.60 \%$ & $\mathrm{z}=2.39$ \\
\hline Passive policy & 0.895 & $*$ & $2.73 \%$ & & \\
\hline
\end{tabular}

\begin{tabular}{|c|c|c|c|c|c|}
\hline $\begin{array}{l}\text { Characteristics of } \\
\text { and statistical diffe } \\
\text { (HR departments a }\end{array}$ & $\begin{array}{l}\text { nemplc } \\
\text { ces bet } \\
\text { gencie }\end{array}$ & & $\begin{array}{l}\text { person } \\
\text { public }\end{array}$ & $\begin{array}{l}\text { ummary of statist } \\
\text { icers) and private }\end{array}$ & \\
\hline $\begin{array}{c}\text { Characteristics } \\
\text { of an unemployed person }\end{array}$ & $\begin{array}{r}\text { Std } \\
\text { No } \\
\text { Me } \\
\text { (Off }\end{array}$ & $\begin{array}{l}\text { lev } \\
\text { nal } \\
\text { n (i } \\
\text { ers }\end{array}$ & $\begin{array}{l}\text { ation } \\
\text { ty (*) } \\
7 \%) \\
=64)\end{array}$ & $\begin{array}{l}\text { Score difference } \\
\text { Private sector } \\
\text { (in \% points) } \\
\text { (Agents = 28) }\end{array}$ & $\begin{array}{l}\text { Statistics } \\
(\mathrm{N}=92)\end{array}$ \\
\hline Passive attitude & 0.488 & * & $62.50 \%$ & $-30.80 \%$ & $z=-2.70$ \\
\hline Only prim. education & 0.495 & * & $59.38 \%$ & & \\
\hline No experience & 0.479 & & $34.38 \%$ & & \\
\hline Travel to work issues & 0.473 & * & $32.81 \%$ & & \\
\hline Older person $\left(55^{+}\right)$ & 0.453 & & $28.13 \%$ & & \\
\hline Racial minority & 0.380 & & $17.19 \%$ & $-17.19 \%$ & $z=-2.33$ \\
\hline Disabled person & 0.350 & & $14.06 \%$ & & \\
\hline Next education issues & 0.333 & & $12.50 \%$ & & \\
\hline No foreign languages & 0.315 & & $10.94 \%$ & $+31.92 \%$ & $z=3.46$ \\
\hline Psychological issues & 0.244 & * & $6.25 \%$ & & \\
\hline Adolescents & 0.244 & * & $6.25 \%$ & & \\
\hline Other issues & 0.244 & * & $6.25 \%$ & & \\
\hline Physical issues & 0.213 & & $4.69 \%$ & & \\
\hline Woman & 0.175 & & $3.13 \%$ & & \\
\hline University graduate & 0.125 & & $1.56 \%$ & $+12.72 \%$ & $z=2.46$ \\
\hline Only sec. education & 0.000 & & $0.00 \%$ & $+7.14 \%$ & $z=2.15$ \\
\hline
\end{tabular}

Source: Questionnaire Note: Binary (Yes/No) questions 


\section{Ekonomie}

Our next set of questions was aimed at the average characteristics of an unemployed person. There are significant differences between the regions in their perceptions of the public sector. In the Ústecký Region, the average unemployed are more likely (+0.48 p.p.) to have only primary education $(z=3.824 ; n=64)$ and $(+0.26$ p.p.) no previous experience. On the other hand in Jihočeský Region the average unemployed person is more likely ( +0.35 p.p.) to travel to work than in the Ústecký Region ( $z=-2.941 ; n=64)$. No other differences between the regions were found. In other words, the rest of the perceptions are regionally independent and the characteristics are similar.

The comparison of the characteristics of an average unemployed person between the public and private sectors shows some substantial differences (see Tab. 5). As is shown, an appropriate education is a key distinction. The private sector is more concerned about the quality of the secondary and tertiary education, and language skills than the passivity or race of the average unemployed person.

Once again the perception of the private sector may be biased. Labour office workers come into contact with the long-term unemployed and troubled individuals who are excluded and not motivated to actively solve their difficult social situation. Officers are therefore more likely to place greater emphasis on the passive attitude of an unemployed person.

Table 6 summarizes the average values for labour market issues of the public sector and the differences between them and recruitment agencies. The absence of job vacancies and high social benefits are accentuated by the officers in comparison with the private recruitment agencies. Here again, the labour office workers are in direct contact with the unemployed and see the combination of a passive attitude, primary education and no work experience (see Tab. 3). These factors in

Tab. 6: Labour market issues - summary of statistics and statistical differences between public (officers) and private sector (HR departments and agencies)

\begin{tabular}{|c|c|c|c|c|c|}
\hline Labour market issues & $\begin{array}{r}\text { Std } \\
\text { No } \\
\text { Me } \\
\text { (Off }\end{array}$ & $\begin{array}{l}\text { iali } \\
\text { n (i } \\
\text { ers }\end{array}$ & $\begin{array}{l}\text { ation } \\
\text { y (*) } \\
\%) \\
=64)\end{array}$ & $\begin{array}{l}\text { Score diffe- } \\
\text { rence } \\
\text { Private sector } \\
\text { (in \% points) } \\
\text { (Agents }=28 \text { ) }\end{array}$ & $\begin{array}{c}\text { Statistics } \\
(\mathrm{N}=92)\end{array}$ \\
\hline High social benefits & 0.366 & & $84.38 \%$ & $-34.38 \%$ & $z=-3.44$ \\
\hline Secondary school graduates & 0.492 & * & $39.06 \%$ & & \\
\hline No job vacancies & 0.484 & * & $35.94 \%$ & $-21.65 \%$ & $z=-2.09$ \\
\hline University graduates & 0.393 & & $18.75 \%$ & & \\
\hline Unemployed qualification & 0.350 & & $14.06 \%$ & $+35.94 \%$ & $z=3.64$ \\
\hline Labour taxation & 0.315 & & $10.94 \%$ & $+17.63 \%$ & $z=2.10$ \\
\hline Bad infrastructure & 0.315 & & $10.94 \%$ & & \\
\hline Other issues & 0.294 & & $9.38 \%$ & & \\
\hline Layoffs (Structural) & 0.270 & & $7.81 \%$ & & \\
\hline Layoffs (Economic cycle) & 0.270 & & $7.81 \%$ & & \\
\hline Racial discrimination & 0.213 & & $4.69 \%$ & & \\
\hline Labour regulation & 0.175 & & $3.13 \%$ & & \\
\hline Female discrimination & 0.175 & & $3.13 \%$ & & \\
\hline Start-up credit issues & 0.125 & & $1.56 \%$ & & \\
\hline High unemployment benefits & 0.000 & & $0.00 \%$ & $+21.43 \%$ & $z=3.81$ \\
\hline High layoff costs & 0.000 & & $0.00 \%$ & $+7.14 \%$ & $z=2.15$ \\
\hline
\end{tabular}


combination with high social benefits and no suitable job vacancies do little to motivate an unemployed person to find a job.

In contrast, the private sector places emphasis on the qualifications of the unemployed and their high unemployment benefits. The emphasis is also the costs associated with layoffs, and labour taxation. It is clear that these factors are all connected to the job applicants. The stress is on the level of education and experience, which is seen as a market problem (see Tab. 4) and the most problematic characteristic of an unemployed person (see Tab. 3).

There are some significant regional public sector differences with regard to the perception of the market situation. The results interestingly show that there are cause-like factors like the level of business taxation $(z=-2.55 ; n=64$; +20.45 p.p.), appropriateness of university education ( $z=-2.67 ; n=64 ;+26.72$ p.p.), appropriateness of secondary education $(z=-1.99 ; n=64 ;+24.90$ p.p.) which are perceived to be of great importance in the Jihočeský Region (JR) labour market by public sector workers.

In contrast, the emphasis in the Ústecký Region is on the absence of job vacancies $(z=2.81 ; n=64 ;+34.62$ p.p.), which is more a long term consequence-like factor of the regional labour market. In other words, the situation in the Ústecký Region is due to the lack of job vacancies for all the unemployed and unemployable. With regards to other factors like the level of infrastructure or discrimination there are no regional differences.

\section{Conclusion}

Active employment policy instruments and passive policy instruments are not perceived by major institutional players as suitable nor very effective in the Czech regional labour markets. Labour office workers are even more sceptical than private recruitment agencies because of their first-hand experience with the passive attitude of unemployed people. Those people that are usually unemployed have no previous job experience, completed only primary education and are not willing to travel to work. The private recruitment agencies stress the need for better qualifications and skills. Because employment policy is not perceived as very efficient the causes need to be addressed. The pressing problem is the quality of education and generous social benefits which makes employment policy inefficient for the least skilled unemployed.

Despite substantial socio-economic regional differences (education level, GDP per capita) in both analysed regions, the evaluation of all the traditional active employment policy instruments is poor with no significant differences between the regions. In the more problematic Ústecký Region the emphasis is on basic issues such as the lack of education and experience of the unemployed. The labour market issues here are the result of long-term consequencelike factors like the lack of job vacancies. The situation in the Jihočeský Region is better. The emphasis here is on mobility. The market issues here are more cause-like factors like the appropriateness of secondary and tertiary education and labour costs.

Our results are to some extent similar to those in previous research. An example of this is the combined issue of the lack of motivation and high social benefits. There are however some differences. On average, passive policy instruments are perceived to be more suitable and effective than the current array of active policy instruments. Deeper analysis shows that social benefits and unemployment benefits are still perceived (in particular by labour office workers) to be bad economic policy.

From our results it is clear that poor institutional infrastructure in secondary and tertiary education causes bad investment in human capital and subsequent disequilibrium in regional labour markets. All the institutional players stress the need for appropriate education, which is problematic. Radical changes were also introduced in education after the fall of the iron curtain in 1989. There was a need to increase the number of university graduates. This marked the start of the so-called "massification" of higher education in the Czech Republic. Studying at universities ceased to be the privilege of gifted students (Večerek et. al., 2010).

The Czech Higher Education Act regulates the framework in which universities operate. The ideal solution for further development was described in the International Competitiveness Strategy of the Czech Republic for the period 2012-2020 (Government of the Czech Republic, 2011). The Strategy highlights the importance of high quality teaching, the role of teachers, and put forward proposals for the better 
organization and financing of the educational sector. Unfortunately, nothing has changed and the old "massification" process still leads to "quantity over quality" despite all the legislators' wishes. A large proportion of education funding is allocated based on the number of students that attend an educational establishment and the quality indicators of universities do not reflect the actual quality.

Respondents from the public sector were given the opportunity in their responses to introduce an employment policy instrument, which they believed would be more suitable than the current active policy instruments. Many respondents even from private sector stated that regional programmes aimed at young people who want to gain some work experience were beneficial. Also regional specific qualification/education programmes were considered to be beneficial. The EURES programmes and The Human Resources and Employment Operational Programmes were also highlighted. These programmes aim to be individual, long-term oriented, multi-objective and find unemployed people jobs abroad and/or in cross-border regions. On the whole, private sector respondents believe that educational reform is necessary and that social benefits should not be so generous or that community work should be required in return.

This paper also contributed to the issue of "The North/South" divide. The perceptions of effectiveness of standard employment policy tools are the same in both regions. It is possible that the past political decisions and inefficient social and economic policy in Ústecký Region led to a slower development; however, more research is needed in this area.

\section{References}

Aoki, M. (2001). Toward a comparative institutional analysis. Massachusetts: The MIT Press.

Bah, E., \& Brada, J. C. (2014). Labor Markets in the Transition Economies: An Overview. European Journal of Comparative Economics, 11(1), 3-53.

Ball, S. J. (2009). Privatising education, privatising education policy, privatising educational research: network governance and the "competition state". Journal of Education Policy, 24(1), 83-99. doi:10.1080/02680930802419474.
CZSO (2015). Český statistický úřad REG_ HDP_O Hrubý domácí produkt na 1 obyvatele. Retrieved June 21, 2015, from http://apl.czso. cz/pll/rocenka/rocenka.presmsocas?jmeno_ tabulka $=$ RC03-1\&rokod $=2013 \&$ rokdo $=2013 \& \bar{m}$ ylang $=E N \&$ ceny $=b c \& v y s t u p=o b r a z o v k a \& p r i z n$ $a k=R C \&$ typ $=2 \& j a k=4 \&$ dejarchiv $=0$.

Dill, D. D., \& Soo, M. (2005). Academic quality, league tables, and public policy: A cross-national analysis of university ranking systems. Higher Education, 49(4), 495-533. doi:10.1007/s10734-004-1746-8.

Flek, V., \& Večerník, J. (2005). The Labor Market in the Czech Republic: Trends, Policies, and Attitudes. Finance a úvěr - Czech Journal of Economics and Finance, 55(1-2), 5-24.

Gërxhani, K., \& Schram, A. (2006). Tax Evasion and Income Source: A Comparative Experimental Study. Journal of Economic Psychology, 27(3), 402-422. doi:10.1016/j. joep.2005.08.002.

González, S. (2011). The North/South divide in Italy and England: Discursive construction of regional inequality. European Urban and Regional Studies, 18(1), 62-76. doi:10.1177/0969776410369044.

Government of the Czech Republic Ministry of Industry and Trade. (2011). Strategie mezinárodni konkurenceschopnosti České republiky pro období 2012 až 2020. Retrieved June 21, 2015, from http://www.msmt.cz/ file/32956_1_1/.

Gupta, R., \& du Toit, C. B. (2009). Active versus Passive Policies of Unemployment: Growth and Public Finance Perspectives. South African Journal of Economic and Management Sciences, 12(1), 1-10.

Holátová, D., \& Řehoř, P. (2006). Socioekonomický rozvoj regionů. Auspicia, 3(2), 51-56.

Kahn, L. M. (2012). Labor market policy: A comparative view on the costs and benefits of labor market flexibility. Journal of Policy Analysis and Management, 31(1), 94-110. doi:10.1002/pam.20602.

Mincer, J. (1958). Investment in Human Capital and Personal Income Distribution. Journal of Political Economy, 66(4), 281-302.

MPSV. (2015). Statistická ročenka trhu práce $v$ České republice 2014. Retrieved June 20, 2015, from http://www.mpsv.cz/files/ clanky/20862/MPSV_rocenka_2014.pdf.

North, D. C. (1991). Institutions. Journal of Economic Perspectives, 5(1), 97-112. doi:10.1257/jep.5.1.97. 
Ostrom, E. (1990). Governing the Commons: The Evolution of Institutions for Collective Action. Cambridge UK: Cambridge University Press.

Pavelka, T. (2012). The Minimum Wage in the Czech Republic - the Instrument for Motivation. In T. Löster, \& T. Pavelka (Eds.), The 6th International Days of Statistics and Economics. Conference Proceedings. September 13-15, 2012, Prague, Czech Republic (pp. 903-911). Praha: Melandrium.

Pavelka, T., Skála, M., \& Čadil, J. (2014). Selected Issues of the Minimum Wage in the Czech Republic. E\&M Ekonomie a Management, 17(4), 30-45. doi:10.15240/ tul/001/2014-4-003.

Rašovec, T. (2014). Analýza vývojových tendenci trhu práce $s$ ohledem na kvalifikační strukturu (Dissertation). Provozně ekonomická fakulta České zemědělské univerzity v Praze. Retrieved May 2, 2015, from www.pef.czu.cz/ $\mathrm{cs} /$ ?dl=1\&f=29014.

Sirovátka, T., \& Mareš, P. (2006). Chudoba, deprivace, sociální vyloučení: nezaměstnaní a pracující chudí. Czech Sociological Review, 42(4), 627-655.

Slemrod, J. (2007). Cheating Ourselves: The Economics of Tax Evasion. The Journal of Economic Perspectives, 21(1), 25-48. doi:10.1257/089533007780095529.

Toušek, V., Smolová, I., Fňukal, M., Jurek, M., \& Klapka, P. (2005). Česká republika: portréty krajů. Praha: Ministerstvo pro místní rozvoj ČR. Retrieved May 12, 2015, from https://is.muni.cz/publication/628628.

Tvrdoň, M. (2008). Institucionální aspekty fungování trhu práce. Politická ekonomie, 56(5), 621-642.

Večerek, V., Vochozka, M., Bílá, J., Kolář, P., Nantl, J., \& Štech, S. (2010). Idea reformy terciárního vzdělávání. Retrieved May 10, 2015, from http://crc.muni.cz/pdf/news/ldea\%20 reformy $\% 20-\% 20 C K R \% 2024.6 .2010$.pdf.
Vlček, P. (2010). Analýza konkurenceschopnosti České republiky. Ministerstvo průmyslu a obchodu. Retrieved May 12, 2015, from http:// download.mpo.cz/get/41230/46014/555208/ priloha001.pdf.

Wawrosz, P., Heissler, H., \& Mach, P. (2012). Reálie k makroekonomii: odborné texty, mediální reflexe, praktické analýzy. Praha: Wolters Kluwer Česká republika.

Welch, B. L. (1947). The Generalization of 'Student's' Problem when Several Different Population Variances are Involved. Biometrika, 34(1/2), 28-35. doi:10.2307/2332510.

Wilcoxon, F. (1945). Individual comparison by ranking methods. Biometrics, 1, 80-83. doi: $10.2307 / 3001968$.

RNDr. Václav Novák, Ph.D. Jan Evangelista Purkyně University in Ústí nad Labem

Faculty of Social and Economic Studies Department of Regional Development and Public Administration vaclav.novak@ujep.cz

Ing. Marek Vokoun, Ph.D. Institute of Technology and Business in České Budějovice

Department of Management marekvokoun@email.cz

doc. PhDr. František Stellner, Ph.D. Institute of Technology and Business in České Budějovice Department of Management stellner@mail.vstecb.cz

doc. Ing. Marek Vochozka, MBA, Ph.D. Institute of Technology and Business in České Budějovice Rector vochozka@mail.vstecb.cz 


\section{Ekonomie}

\section{Appendix 1: Questionnaire}

1. Please choose three of the most urgent problems in the labour market in the Ústecký Region / Jihočeský Region at the present time.

We are interested in factors affecting the creation of new jobs and the demand for them. We are interested in your experience and points of view. If the most acute problems are not identified in this form, please use the field "other" to make them known.

- Unemployed lack sufficient qualifications

- Dismissal due to a drop in demand (no new contract)

- The structure of the subjects taught at secondary school does not meet the needs of the labour market

- The high cost of dismissing employees

- Poor infrastructure in the region

- The structure of the subjects taught at university does not meet the needs of the labour market

- Racial discrimination in the labour market

- Layoffs due to changes in the structure of the sector (industries are technologically obsolete)

- High unemployment benefits

- High taxes and premiums for social and health insurance

- Difficult to obtain a loan to start-up or develop a business

- Strong regulation of labour law relations

- Excessive influence of trade unions

- Lack of jobs

- Social benefits not conducive to a return to work

- Discrimination against women in the labour market

- Minimum wage is too high

- Other: \&

\section{Please select the three items that best characterize the typical job seeker in the Ústecký} Region / Jihočeský Region. *

We are interested in your experience and points of view. If you feel that an important characteristic is missing from the list, please use the field "other" to make it known.

- Unwillingness to follow further education

- Racial minority

- Passive approach (to search for employment, employment programmes)

- The individual only completed elementary school

- Impaired physical health (e.g. lifestyle diseases)

- Female

- Unwillingness to retrain

- Person with disability

- Does not speak a/any foreign language(s)

- Impaired psychological health condition (e.g. stress, anxiety, difficulty in communicating, etc.)

- Cultural minority

- Religious minority

- College graduate

- Over 55 years of age

- Not willing to travel for work

- Minors (under 18 years)

- High school graduate

- Lack of experience (or no previous job)

- Sexual minority

- Other: \& 
3. Please indicate the three positions that lack the most candidates/qualifications which candidates lack in your region at present.

1. position/qualifications lacking candidates:

2. position/qualifications lacking candidates

3. position/qualifications lacking candidates

4. State employment policy - ratings

On a scale of 1 to 5 rate the current employment policy instruments in the Ústecký Region and their impact on employment levels.

1 - very helpful, 2 - beneficial, 3 - neutral, 4 - rather inconvenient, 5 - inappropriate

\subsection{Job retraining (through Labour Office)*}

\begin{tabular}{l|l|l|l|l|l|l} 
& 1 & 2 & 3 & 4 & 5 & \\
\hline Very helpful & $\circ$ & $\circ$ & $\circ$ & $\circ$ & $\circ$ & Inappropriate
\end{tabular}

\subsection{Public works (PW)*}

\begin{tabular}{l|c|c|c|c|c|c} 
& 1 & 2 & 3 & 4 & 5 & \\
\hline Very helpful & $\circ$ & $\circ$ & $\circ$ & $\circ$ & $\circ$ & Inappropriate
\end{tabular}

4.3 Socially beneficial jobs (SBJ)*

\begin{tabular}{l|l|l|l|l|l|l} 
& 1 & 2 & 3 & 4 & 5 & \\
\hline Very helpful & $\circ$ & $\circ$ & $\circ$ & $\circ$ & $\circ$ & Inappropriate
\end{tabular}

\subsection{Consultancy (at Labour Offices)*}

\begin{tabular}{l|c|c|c|c|c|r} 
& 1 & 2 & 3 & 4 & 5 & \\
\hline Very helpful & $\circ$ & $\circ$ & $\circ$ & $\circ$ & $\circ$ & Inappropriate
\end{tabular}

4.5 Support for the employment of persons with disabilities*

\begin{tabular}{l|c|c|c|c|c|r} 
& 1 & 2 & 3 & 4 & 5 & \\
\hline Very helpful & $\circ$ & $\circ$ & $\circ$ & $\circ$ & $\circ$ & Inappropriate
\end{tabular}

4.6 Unemployment benefits (cash assistance, passive employment policy)*

\begin{tabular}{l|c|c|c|c|c|r} 
& 1 & 2 & 3 & 4 & 5 & \\
\hline Very helpful & $\circ$ & $\circ$ & $\circ$ & $\circ$ & $\circ$ & Inappropriate
\end{tabular}

4.7 If you wish to evaluate another instrument (e.g. European programme, a form of support not listed above, etc.) please use the following field (optional).

[text-area] 


\section{Ekonomie}

5. Please indicate any instrument of employment policy you would suggest should be introduced (or extended, modified, upgraded) in your region or in the Czech Republic (optional).

[text-area]

For any additional information on this issue which you wish to share please use the following field (optional).

[text-area]

If you wish to receive the results of this study electronically, please enter your e-mail address in the following field (optional).

[text-area]

To be listed in the introduction of this study as our collaborator, please provide your name, title(s) and the institution which you represent in the following field (optional). Name, surname, title, institution (e.g. Jana, Nebeská, Ing., Ph.D., City of Ústí nad Labem) [text-area]

\begin{tabular}{c|c|c|c|c}
\multicolumn{5}{c}{$\begin{array}{c}\text { Employment market policies measures. Summary of passive (PEMP) } \\
\text { and active (AEMP) employment market policies expenditures per one } \\
\text { unemployed person in the Czech Republic between 2005 and 2014 }\end{array}$} \\
\cline { 1 - 3 } Year & Unemployed (thousands) & PEMP & AEMP & EMP \\
\hline 2005 & 410.2 & 17,181 CZK & 10,172 CZK & 29,510 CZK \\
\hline 2006 & 371.3 & 19,681 CZK & 14,279 CZK & 38,254 CZK \\
\hline 2007 & 276.3 & 25,389 CZK & 20,534 CZK & 54,548 CZK \\
\hline 2008 & 229.8 & 30,957 CZK & 26,682 CZK & 68,229 CZK \\
\hline 2009 & 352.2 & 42,811 CZK & 14,067 CZK & 65,684 CZK \\
\hline 2010 & 383.7 & 34,810 CZK & 16,088 CZK & 59,265 CZK \\
\hline 2011 & 350.6 & 29,521 CZK & 10,887 CZK & 50,881 CZK \\
\hline 2012 & 366.9 & 23,875 CZK & 7,075 CZK & 41,634 CZK \\
\hline 2013 & 368.9 & 26,223 CZK & 11,616 CZK & 48,691 CZK \\
\hline 2014 & 323.6 & 28,677 CZK & 19,861 CZK & 62,169 CZK \\
\hline Mean & $\mathbf{3 4 3 . 3}$ & $\mathbf{2 7 , 9 1 3 ~ C Z K}$ & $\mathbf{1 5 , 1 2 6 ~ C Z K}$ & $\mathbf{5 1 , 8 8 6 ~ C Z K}$ \\
\hline
\end{tabular}

Source: Ministry of Labour and Social Affairs, Čerpáni finančních prostředků na státní politiku zaměstnanosti v období 2003-2014. Note: EMP aggregate consists of PEMP, AEMP and other EMP tools expenditures. 


\title{
Abstract
}

\section{INSTITUTIONAL ANALYSIS OF THE CONTEMPORARY REGIONAL LABOUR MARKET IN THE CZECH REPUBLIC}

\author{
Václav Novák, Marek Vokoun, František Stellner, Marek Vochozka
}

Public institutions are key players in the regional labour markets in the Czech Republic. Their activities are constrained by economic policies, which are aimed at increasing employment and the efficiency of the labour markets. Our analysis uses a questionnaire to collect data from the institutions and evaluate their perception of the regional labour market. The results suggest that active employment policy instruments and passive policy instruments are perceived as inefficient and inappropriate. The unemployed usually have no previous job experience, completed only primary education and are not willing to travel to work. The pressing problem is the quality of education and the generous social benefits that makes employment policy inefficient for the least skilled unemployed. Despite substantial regional socio-economic differences in both analysed regions (the Ústecký Region and the Jihočeský Region), there are no significant differences in the poor evaluation of all the traditional active employment policy instruments. In the more problematic Ústecký Region the emphasis is put on basic issues such as the lack of education and experience of the unemployed. The local labour market issues are dictated by long-term factors such as the lack of job vacancies. In the Jihočeský Region the situation is better. The issue is more one of mobility. The market issues here are more related to the appropriateness of secondary and tertiary education and labour costs. To increase the efficiency of employment policies we recommend improvements to the institutional infrastructure in higher education, which should be oriented towards investment in the quality of human capital.

Key Words: Institutions, labour market, economic policy, education.

JEL Classification: E2, J4, J6.

DOI: 10.15240/tul/001/2016-3-001 